\section{Randomized Controlled Trial Study of the Impact of a Spiritual Intervention on Hope and Spiritual Well-Being of Persons with Cancer}

\author{
Ardashir Afrasiabifar ${ }^{1,5}$ \\ https://orcid.org/0000-0001-5272-6012 (D) \\ Asadollah Mosavi 2,5 \\ https://orcid.org/0000-0002-7792-7379 iD \\ Abolfazl Taghipour Jahromi ${ }^{3,5}$ \\ https://orcid.org/0000-0003-3906-2922 iD \\ Nazafarin Hosseini ${ }^{4,5}$ \\ https://orcid.org/0000-0001-7471-7475 (iD
}

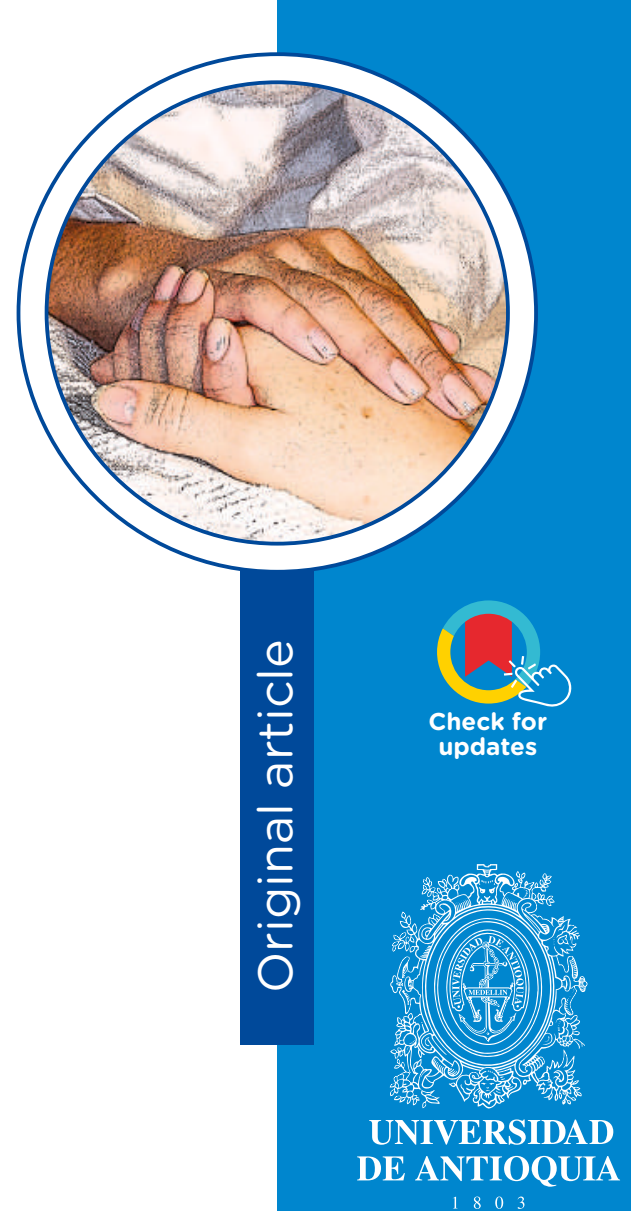

1 Professor, Ph.D.

Email: afrasiabifar.ardashir@yums.ac.ir

2 Nurse Instructor, M.Sc.

Email: mosaviasadolah@yahoo.com.

Corresponding author.

3 Nurse, M.Sc. Email: ataghpour38@gmail.com

4 Associate Professor, Ph.D.

Email: hosseinichenar@yahoo.com

5 School of Nursing, Yasuj University of Medical Sciences, Yasuj, Iran

Conflicts of interest: None.

Receipt: February 1, 2021.

Approved: September 3, 2021.

How to cite this article: Afrasiabifar A, Mosavi A, Jahromi AT, Hosseini N. A Randomized Controlled Trial Study of the Impact of a Spiritual Intervention on Hope and Spiritual Well-Being of Patients with Cancer. Invest. Educ. Enferm. 2021; 39(3):e08.

DOI: https://doi.org/10.17533/udea.iee.v39n3e08.

the control group had received usual cares. Data were collected using Snyder's Hope Scale and Ellison's Scale Spiritual Well-Being Scale on a week before and after intervention. Results. The total mean scores of the scales of hope and spiritual well-being in both groups did not

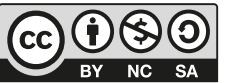

https://creativecommons.org/licenses/by-nc-sa/4.0 
present statistical differences in the pre-intervention assessment. In contrast, at the post assessment, significant differences $(p<0.001)$ were found in the mean scores between the intervention and control groups on the hope scale (60.9 versus 39.8 ) and on the spiritual well-being scale (94.3 versus 71.6$)$. Conclusion. Spiritual intervention could promote hope and spiritual well-being of persons with cancer.

Descriptors: patiens; neoplasms; hope; spirituality.

\section{Ensayo controlado aleatorio sobre el impacto de una intervención espiritual en la esperanza y el bienestar espiritual de los personas con cáncer}

\section{Resumen}

Objetivo. Determinar el impacto de una intervención espiritual en la esperanza y el bienestar espiritual de las personas con cáncer. Métodos. Ensayo controlado aleatorio en el que participaron 74 pacientes con cáncer que acudieron a una sala de quimioterapia del Hospital Shahid Rajaie de la ciudad de Yasuj (Irán). Los pacientes elegibles se asignaron aleatoriamente al grupo de intervención o al de control. Durante 5 sesiones, y antes de la quimioterapia, se llevó a cabo una intervención espiritual basada en un protocolo con cuatro campos principales: religioso, existencia, emocional y social. Los participantes en el grupo control recibieron el cuidado usual. Los datos se recogieron mediante la aplicación de la escala de esperanza de Snyder, una semana antes y una semana después de la intervención, y de la escala de bienestar espiritual de Ellison. Resultados. Las puntuaciones medias de las escalas de esperanza y bienestar espiritual en ambos grupos no presentaron diferencias estadísticas en la evaluación pre-intervención. En cambio, en la evaluación posterior, se encontraron diferencias significativas $(p<0.001)$ en las puntaciones medias entre los grupos de intervención y de control en la escala de esperanza (60.9 frente a 39.8) y en la escala de bienestar espiritual 
(94.3 frente a 71.6). Conclusión. La intervención espiritual podría promover la esperanza y el bienestar espiritual de las personas con cáncer.

Descriptores: pacientes; neoplasias; esperanza; espiritualidad.

\section{Ensaio controlado aleatório sobre o impacto de uma intervenção espiritual na esperança e no bem-estar espiritual de pessoas com câncer}

Resumo

Objetivo. Determinar o impacto de uma intervenção espiritual na esperança e no bem-estar espiritual das pessoas com câncer. Métodos. Ensaio controlado aleatório envolvendo 74 pacientes com câncer que frequentaram uma sala de quimioterapia no Hospital Shahid Rajaie na cidade de Yasuj (Irã). Os pacientes elegíveis foram aleatoriamente designados para o grupo de intervenção ou controle. Durante 5 sessões, e antes da quimioterapia, foi realizada uma intervenção espiritual baseada em um protocolo com quatro campos principais: religioso, existencial, emocional e social. Os participantes do grupo controle receberam os cuidados habituais. Os dados foram coletados por meio da aplicação da Escala de Esperança de Snyder e da Escala de Bem-Estar Espiritual de Ellison uma semana antes e uma semana após a intervenção. Resultados. Os escores médios das escalas de esperança e bem-estar espiritual em ambos os grupos não apresentaram diferenças estatísticas na avaliação pré-intervenção. Por outro lado, na avaliação subsequente, foram encontradas diferenças significativas $(p<0.001)$ nas pontuações médias entre os grupos intervenção e controle na escala de esperança (60.9 vs. 39.8 ) e na escala de bem-estar espiritual (94.3 vs. 71.6). Conclusão. A intervenção espiritual pode promover esperança e bem-estar espiritual para pessoas com câncer.

Descritores: patients; neoplasias; esperança; espiritualidade. 


\section{Introduction}

The diagnosis of cancer is considered as a crisis by patients and their families in the most times.(1) In addition, the effect of cancer on patients' physical and psychosocial health, ${ }^{(2)}$ cancer may reduce their life expectancy due to re-hospitalization and complications of treatment. ${ }^{(3)}$ Re-hospitalization is sometimes accompanied by unsuccessful treatment, reduced physical, psychological and spiritual well-being. It may also lead to lack of the patient's ability to find meaning of life, ${ }^{(4)}$ to be hopefulness and spiritual distress. ${ }^{(5)}$ The results of a study indicated that patients with cancer need supports to overcome fear $(57 \%)$, hope (58\%), meaningful life (50\%), and negotiation regarding to dying and death (29\%). ${ }^{(1)}$ Review of literatures also shows contradictory findings about the effects of religious and spiritual interventions. The results of some studies have shown positive effects such as; better tolerance of disease, ${ }^{(6)}$ better adherence to therapeutic regimes, ${ }^{(7)}$ improved self-esteem, ${ }^{(8)}$ lower depression and anxiety, ${ }^{(9)}$ and more hope of life ${ }^{(10)}$ following religious or spiritual interventions. On contrast, some studies have reported negative consequences such as anger toward God, anxiety and depression ${ }^{(11)}$ and even thoughts of suicide. ${ }^{(12)}$

Moreover, patients with cancer want to meet their spiritual needs which may not be necessarily religious needs. Because the meaning and purpose of life is based on a belief system even in people who have no religious beliefs. ${ }^{(13)}$ Studies show that patients increase their demands to meet spiritual needs while facing lethal diseases such as cancer. ${ }^{(14)}$ Assessing spiritual needs and designing interventions based on spiritual needs results in effective adaptation, improved quality of life, and also better interaction with therapeutic plans. ${ }^{(15)}$

Despite these emphases, the available evidences suggest that holistic cares comprising all aspects of human existence such as physical, mental, social and spiritual aspects has not been considered and especially that patients with cancer had repeatedly reported unmet spiritual needs. ${ }^{(2)}$ Furthermore, spiritual needs of patients with cancer were less considered in oncology wards due to the lack of professional understanding of such needs. ${ }^{(16)}$ Oncologist nurses ought to identify spiritual needs of patients with cancer and meet them through qualified cares. ${ }^{(4)}$ They have golden opportunities to provide spiritual care to patients in need. They can improve patients' spiritual wellbeing due therapeutic communication with them. ${ }^{(17)}$ Patients with cancer need both physical cares and psychological support to cope with a wide range of challenges from the time of diagnosis to the course of treatment. ${ }^{(18)}$ The main question of the present study was; whether the spiritual based intervention could improve spiritual well-being and hope in patients with cancer who were aware of their disease. Therefore, the present study aimed to examine the impact of spiritual-based intervention on hope and spiritual well-being in patients with cancer. 


\section{Methods}

Design and Participants. This study is a randomized controlled trial research. The study population was patients with cancer referring to a single chemotherapy ward of Yasuj city, Iran, 2017-2018. One hundred and three patients were assessed for eligibility, however, 80 eligible patients were selected through non-random sampling method and then randomly assigned to one of the two groups of intervention (group A) or control (group B) using block randomization. At first, the groups of intervention and control was labeled with $A$ and $B$ letters, respectively. Next, two blocks namely; $A B, B A$ was created based on the statistical factorial rule $(2$ !: $2 \times 1=2)$ since we had two groups in this study. Therefore. We had two participants in each block in which their arrangement differed from each other. We selected blocks from these two blocks using replacement random sampling until the participants of our study were completed. Eighty eligible participants were assigned to one of these two groups (forty participants in each group). However, 74 patients completed this study (4 patients died and 2 patients were reluctant to continue the study). (Diagram 1). The blocked random allocation was designed by the first author, however, participants' enrollment and assignment to one of the two groups was conducted by the second author of the article.

Inclusion and Exclusion Criteria. Final diagnosis of cancer, undergoing the chemotherapy, range of age: 20-70 years old, patient's awareness of diagnosis, low score of spiritual well-being and hope based on the applied scales and informed consent to participate were considered as the inclusion criteria of this study. Patient's unwillingness to participate in the study and unmet inclusion criteria were considered to be the exclusion criteria of this study.

Intervention. Spiritual intervention was implemented based on a proposed protocol by Bussing et al. ${ }^{(2)}$ in four domains of religious (excellence), existence (meaning and purpose), emotional (relaxation) and social (communication). It was performed over five sessions before starting chemotherapy in the ward (Table 1). The duration of sessions varied from 30 to 50 minutes. The applied strategies in this intervention included interactive negotiation, mutual questioning and answering, short audio or video clips, book introduction, booklet, and expressing personal experience related to the above four domains. Intervention had been performed by the third author of this article who is a nurse with clinical experience working in oncology settings as well as with supporting of a spiritual counselor. The participants in the control group had received usual cares. 


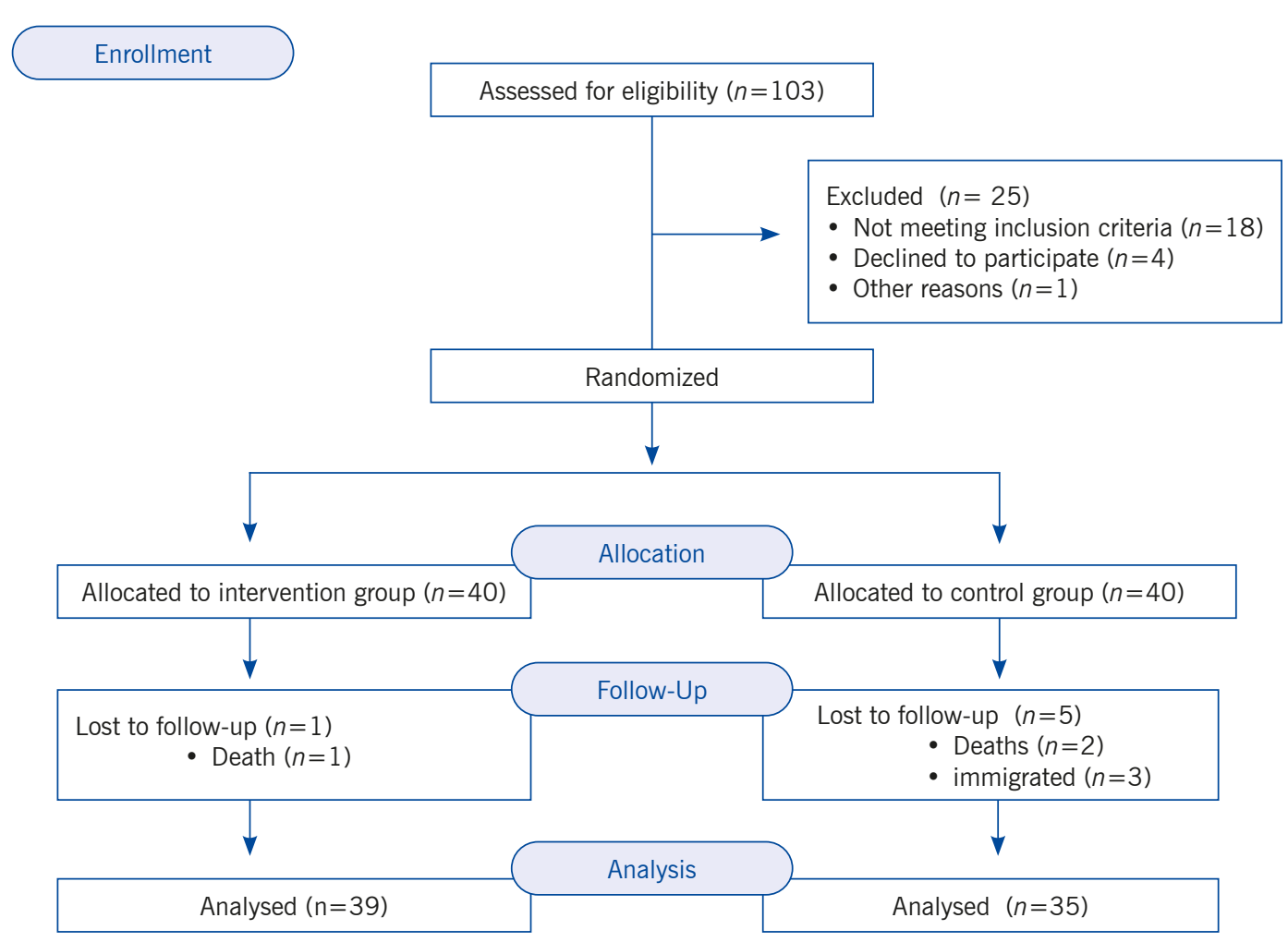

Diagram 1. Consolidated Standards of Reporting Trials (CONSORT) of the study

Table 1. Spiritual based Intervention Protocol

\begin{tabular}{|c|c|c|c|}
\hline Session & Domain & Main theme & Spirituality-based care \\
\hline First & Introduction & Patient's Preparation & Statement of goals and explanation about the intervention \\
\hline Second & Religious & Excellence & Spiritual resources, relationship with God, Sanctities, Worship \\
\hline Third & Existence & Meaning and purpose & Meaning of life, Self-Actualization, role function \\
\hline Fourth & Emotional & Relaxation & Inner calmness, hope, balance, forgiveness, distress, fear \\
\hline Fifth & Social & Communication & $\begin{array}{l}\text { Love and sense of belonging, unity, relationship with spouse, family } \\
\text { and friends }\end{array}$ \\
\hline
\end{tabular}

Outcome measure. Snyder's Hope Scale, and Paloutzian and Ellison's Spiritual Well-Being Scale (SWBS) were used to collect data. Although the Hope Scale consists of 12 items, however, four items are not included for data analysis due to their deviant nature. Two subscales of factor and strategy (4 questions for each subscale) with an eight- point Likert-type scoring of 1-8 are defined. A score of 1 means completely disagree and score 8 shows completely agree. The global score of hope ranges from 8 to 64 . Higher scores represent better levels of hope. The validity and 
reliability of the Hope Scale were approved in Persian. ${ }^{(19)}$ The SWBS, with a six- point Likerttype scale of 1-6, was used to assess spiritual well-being. It has two subscales of religious and existential well-being (each of which with 10 items). A score of 1 shows completely disagree and score 6 represents completely agree. The scores of each subscale range from 10 to 60 . The global score of spiritual well-being ranges from 20 to 120 . The scores of spiritual well-being of 2040 represent low spiritual well-being, scores of 41-99 show moderate spiritual well-being, and scores of 100-120 means high spiritual wellbeing. The psychometric properties of Persian version of the SWBS were approved. (20) We again checked its reliability using Cronbach's alpha that it was verified by our study and found a result of $\boldsymbol{\alpha}=0.78$.

Data Analysis. Data were collected at a week before intervention as baseline and a week post intervention. The collected data was analyzed using SPSS (Version 21) and through descriptive and inferential statistics such as Chi- square, and Fisher's Exact test for nominal variables. The results of independent samples $t$ test and paired samples $t$ test were reported for between and within group comparisons, respectively. Since the data distribution of the scores of outcome variables were normal. $P$ values less than 0.05 were statistically considered significant differences.

Ethical Considerations. The informed consent was signed by the participants after explaining purpose of the study. We emphasized the confidentiality of collected data, the voluntary participation and also voluntary withdrawal at each stage of the study. The present study was approved by the Ethics Committee of Yasuj University of Medical Sciences (YUMS) with an ID code; IR.YUMS. REC.1396.137 and the registered number; IRCT20121208011692N2 by website of the Iranian Clinical Trial.

\section{Results}

In the present study, 39 (52.7\%) of 74 patients with cancer were in the intervention group and 35 patients $(47.3 \%)$ were in the control group. The patients had a mean age of 52.9 years $(S D=18.1)$ with (Range; 20-68 years old) (Table 2). The results of the study related to the scale of hope shows that there was no significant difference in mean scores of hope between the two groups in the pre- intervention assessment. However, in the post- intervention, Independent Samples t test for between group comparison indicates significant differences $(p<0.001)$ in global mean scores of hope and also subscales of factor and strategy for the patients in the intervention group compared with the patients in the control group (Table 3). In addition, mean differences for global scores of hope (13.7), and sub-scales of factor (6.6) and strategy (7.2) are observed for the patients in the intervention group. These mean differences were statistically significant based on the results of Paired Samples $t$ test $(p<0.001)$.

The results of the study related to the scale of spiritual well-being shows that there were no significant differences in mean scores of spiritual well-being between the two groups in the preintervention assessment. On contrast, our findings indicate significant differences for global mean scores of spiritual well-being and subscales of existence well-being, and religious well-being following spiritual intervention compared with the control group (table 4). The results of Paired Samples $t$ test in within group comparison, presents statistical mean difference for global spiritual well-being (21.7), subscales of existential well-being (12.4) and religious well-being (9.2) for the patients in the intervention group, but no significant mean differences are observed for the patients in the control group. 
Table 2. Participants' demographic characteristic by groups

\begin{tabular}{|c|c|c|c|c|c|}
\hline Variables & Group & $\begin{array}{c}\text { Intervention } \\
n=39\end{array}$ & $\begin{array}{c}\text { Control } \\
n=35\end{array}$ & $\begin{array}{c}\text { Total } \\
n=74\end{array}$ & p-value \\
\hline \multicolumn{2}{|l|}{ Age: Mean $\pm S D$} & $20.4 \pm 51.9$ & $16.1 \pm 53.9$ & $18.1 \pm 52.9$ & 0.6 \\
\hline \multicolumn{2}{|c|}{ Duration of cancer diagnosis: Mean $\pm \mathrm{SD}$} & $14.1 \pm 15.2$ & $10.6 \pm 16.4$ & $12.5 \pm 15.8$ & 0.6 \\
\hline \multicolumn{2}{|c|}{ Duration of chemotherapy: Mean \pm SD } & $6.1 \pm 7.5$ & $5.1 \pm 6.7$ & $5.5 \pm 7.1$ & 0.7 \\
\hline \multirow[t]{2}{*}{ Sex: $n(\%)$} & Male & $25(64.1)$ & $17 \quad(48.6)$ & $42(56.7)$ & \multirow{2}{*}{0.2} \\
\hline & Female & $14(35.9)$ & $18(56.3)$ & $32(43.3)$ & \\
\hline \multirow{2}{*}{$\begin{array}{c}\text { Marital status } \\
n(\%)\end{array}$} & Single & $2(5.1)$ & $(17.1)$ & $8(10.8)$ & \multirow{2}{*}{0.09} \\
\hline & Married & $37(94.9)$ & 29(82.9) & $66(89.2)$ & \\
\hline \multirow{3}{*}{$\begin{array}{c}\text { Education } \\
n(\%)\end{array}$} & Primary & $26(66.7)$ & $26(74.3)$ & $52(70.4)$ & \multirow{3}{*}{0.08} \\
\hline & Secondary school & $4(10.3)$ & $7(20)$ & $11(14.8)$ & \\
\hline & Diploma and higher & $9(23.1)$ & $2(5.7)$ & $11(14.8)$ & \\
\hline
\end{tabular}

Table 3. Mean scores of hope in both the intervention and control groups

\begin{tabular}{cccccc}
\multicolumn{2}{c}{$\begin{array}{c}\text { Group } \\
\text { Dimension / Time }\end{array}$} & $\begin{array}{c}\text { Intervention } \\
\text { Mean } \pm \text { SD }\end{array}$ & $\begin{array}{c}\text { Control } \\
\text { Mean } \pm \text { SD }\end{array}$ & \multicolumn{2}{c}{ Independent Samples $t$ test } \\
Factor & Pre & $3.1 \pm 23.7$ & $2.21 \pm 20$ & Mean difference & $p$-value \\
\multirow{2}{*}{ Strategy } & Post & $1.34 \pm 30.3$ & $2.4 \pm 19.8$ & 10.7 & 0.1 \\
& Pre & $3.2 \pm 23.5$ & $2.1 \pm 21.7$ & 1.8 & 0.001 \\
Global Hope & Post & $1.3 \pm 30.7$ & $1.7 \pm 19.9$ & 10.8 & 0.2 \\
& Pre & $5.1 \pm 47.2$ & $3.7 \pm 44.4$ & 2.8 & 0.001 \\
& Post & $2.1 \pm 60.9$ & $3.3 \pm 39.8$ & 21.1 & 0.06 \\
\hline
\end{tabular}

Table 4. Mean scores of spiritual well-being in both the intervention and control groups

\begin{tabular}{lccccc}
\multicolumn{2}{c}{\begin{tabular}{c} 
Group \\
\multicolumn{1}{c}{ Dimension / Time }
\end{tabular}} & & $\begin{array}{c}\text { Intervention } \\
\text { Mean } \pm \text { SD }\end{array}$ & $\begin{array}{c}\text { Control } \\
\text { Mean } \pm \text { SD }\end{array}$ & \multicolumn{2}{c}{$\begin{array}{c}\text { Independent Samples } \boldsymbol{t} \text { test } \\
\text { Mean difference }\end{array}$} & $\boldsymbol{p}$-value \\
Religion health & Pre & $39.8 \pm 9$ & $36.4 \pm 2.6$ & 3.4 & 0.06 \\
& Post & $49 \pm 1.3$ & $36.7 \pm 2.3$ & 12.3 & 0.001 \\
Existential health & Pre & $32.9 \pm 7$ & $34.7 \pm 2.3$ & 1.8 & 0.3 \\
& Post & $45.3 \pm 3.7$ & $34.9 \pm 2.3$ & 10.4 & 0.001 \\
Global Spiritual Well- & Pre & $72.6 \pm 6.3$ & $70.9 \pm 3.1$ & 1.7 & 0.05 \\
being & Post & $94.3 \pm 4.7$ & $71.6 \pm 2.9$ & 22.7 & 0.001 \\
\hline
\end{tabular}




\section{Discussion}

According to the question of this study, the findings indicated that the spiritual- intervention improved spiritual well-being and hope in patients with cancer undergoing the chemotherapy. In other words, respond to spiritual needs led to positive changes in spiritual well-being and hopefulness. (21) The findings of this study is similar to published studies which have indicated benefits of social support,, ${ }^{(22)}$ quality of life, ${ }^{(23)}$ patient's recovery, ${ }^{(7)}$ and strengthened and facilitated interpersonal communication, ${ }^{(24)}$ reduced symptoms and frustration $^{(25)}$ following spiritual or religious interventions. Finding of a qualitative survey by Zumstein-Shaha and colleagues showed that patients with cancer in struggling with disease often use religion/spirituality and rituals to find meaning. ${ }^{(26)}$ Another correlational study has showed that cancer patients undergoing chemotherapy who had a high religious/spiritual coping score were found to have a higher level of hope. (27) The results of a study by Mansurifard and colleagues indicated spiritual health of adolescents with cancer was promoted following spiritual cares, ${ }^{(28)}$ which is in line with our study. However, the findings of our study is not similar to a study by Kang and colleagues, in which meaning of life of adolescents with advanced cancer had been improved following logo therapy, however, no significant changes were observed for spiritual well-being in both the intervention and control groups. ${ }^{(29)}$ A study by Delavari and Nasirian showed improved mental health and reduced anxiety in mothers of children with cancer following logo therapy. ${ }^{\left({ }^{30}\right)}$ On contrast, failure to provide spritual care is associated with spiritual distress, then increased healthcare costs, risk of depression and anxiety(31) which are important challenges to meet spiritual needs of patients with cancer. ${ }^{(32)}$

Despite reporting similar results in the mentioned studies, they also have methodological limitations that should be considered when comparing their results. Providing spiritual cares to patients with cancer is an interdisciplinary work including oncologists, oncology nurses, chaplains, psychologists and even patients with cancer and families. There is a fact that both patients with cancer search spiritual support such as hope, meaning, spiritual well-being interdisciplinary team agree that spiritual supports promote spiritual health of patients in oncology settings. (33) Assessing spiritual needs and recognize spiritual distresses of patients with cancer are key elements of holistic care. ${ }^{(34)}$ Patients with cancer may experience spiritual distress due to uncertainty regarding prognosis and deteriorating health, cancer recurrence. ${ }^{(35)}$ Indicators of hope and spiritual well-being are important in this regard. ${ }^{(36)}$ Moreo er, spirituality is considered as an important predictor of emotional, functional, social well-being and quality of life of patients and families with cancer. ${ }^{(37)}$

Strength and Limitations. Randomized allocation is strength of this study. However, the current study has some limitations that caution in needed when generalizing its results. First, the current study was conducted in a single chemotherapy ward in which all participated patients were Muslims with same belief system. Thus, the participants did not have a diverse religious profile. Belief system may be used as strategy to cope with life-threatening diseases like cancer. Second, spirituality is a multidimensional and absolutely individual concept, ${ }^{(38)}$ which may be associated with religion. (2) Religious people exhibit less spiritual distress due to higher psychosocial adaptation. ${ }^{(39)}$ Patients with cancer may rely on religious issues as important adaptive resources due to the lethal nature of cancer. ${ }^{(40)}$ The results of some studies have shown that patients' spiritual needs vary based on their religious beliefs; and patients without religious beliefs had lower levels of hope and well-being than patients with religious beliefs $^{(41,42)}$ Thus, future studies with designing different religious affiliations and ethnicity are suggested to better clinical judgment regarding the impacts of spiritual based interventions. More investigations eliciting patients' responses can 
help to better understand influence of spirituality and religious on patients and their needs throughout the trajectory of a cancer diagnosis, treatment, and transition to end of life. In this ways, Spirituality interventions will be supported in clinical practice by evidence based nursing.

Conclusion. The present study indicated that the spiritual-based intervention could improve the spiritual well-being and hope in patients with cancer. The importance of providing spiritual interventions to meet cancer patients' spiritual needs such as hope and spiritual well-being is again highlighted by this study. Spiritual interventions as an important component of holistic care should be incorporated into the plan of nursing cares for both patients with cancer and families. Indicators such as spiritual well-being and hope are helpful to assess the effectiveness of these types of interventions in patients with cancer. Our study was a small research in a single chemotherapy, however, further investigations is needed in this area on cancer survivors, patients at the end of life as well as caregivers. Moreover, further research with different settings or the study populations with different sociocultural contexts may be useful to understand how spirituality affect patient to cope with cancer from at the point of diagnosis, treatment, disease progression and even facing with his/her own mortality.

Acknowledgments. We sincerely thank the patients, staff and authorities of Yasuj Shahid Rajaee Hospital for their supports to conduct this study.

\section{References}

1. Timmons A, Gooberman-Hill R, Sharp L. The multidimensional nature of the financial and economic burden of a cancer diagnosis on patients and their families: qualitative findings from a country with a mixed public-private healthcare system. Support Care Cancer. 2013; 21(1):107-17.

2. Büssing A, Koenig HG. Spiritual needs of patients with chronic diseases. Religions. 2010; 1(1):18-27.

3. Baade P D, Youlden D R, Andersson T M, Youl P H, Kimlin M G, Aitken J F, Biggar R J. Estimating the change in life expectancy after a diagnosis of cancer among the Australian population. BMJ Open 2015; 5:e006740.

4. Hassankhani H, Amin Soheili A, Hosseinpour I, Eivazi Ziaei J, Nahamin M. A comparative study on the meaning in life of patients with cancer and their family members. J. Caring Sci. 2017; 6(4): 325-33.

5. Puchalski CM, King SDW, Ferrell BR. Spiritual considerations. Hematol Oncol Clin North Am. 2018;32(3):505-17.

6. Balducci L. Geriatric Oncology, spirituality, and palliative care. J. Pain Symptom Manag. 2019; 57(1):171-75.

7. Javanmardifard S, Heidari S, Sanjari M, Yazdanmehr M, Shirazi F. The relationship between spiritual well-being and hope, and adherence to treatment regimen in patients with diabetes. J. Diabetes Metab. Disord.2020;19:941-50

8. Abbasian F, kia N, Mirmohammadkhani M, Ghahremanfard F, Ghods E. Self-esteem and spiritual health in cancer patients under chemotherapy in Semnan University of Medical Sciences in 2014. Health Spiritual Med. Ethics. 2016; 3(4):29-37

9. Nasution LA, Afiyanti Y, Kurniawati W. Effectiveness of spiritual intervention toward coping and spiritual well-being on patients with gynecological cancer. Asia Pac. J. Oncol. Nurs. 2020; 7(3):273-9.

10. Rogers M, Wattis J. Spirituality in nursing practice. Nurs. Stand. 2015; 29(39):51-7.

11. Hebert R, Zdaniuk B, Schulz R, Scheier M. Positive and negative religious coping and well-being in women with breast cancer. J. Palliat. Med. 2009; 12(6):537-45.

12. Grover S, Sarkar S, Bhalla A, Chakrabarti S, Avasthi A. Religious coping among self-harm attempters brought to emergency setting in India. Asian J. Psychiatr. 2016; 23:78-86.

13. Wolf S. Meaning in life and why it matters. Princeton University Press; 2010.

14. Ghahramanian A, Davoodi A, Khorrami Markani A, Bahrami A. Spiritual needs of patients with cancer referred to Alinasab and Shahid Ghazi Tabatabaie Hospitals of Tabriz, Iran. Asian Pac. J. Cancer Prev. 2016;17 (7):3105-9. 
15. Ciarrochi J, Parker P, Kashdan TB, Heaven PC, Barkus E. Hope and emotional well-being: A six-year study to distinguish antecedents, correlates, and consequences. J. Posit. Psychol. 2015; 10(6):520-32.

16. Arndt V, Koch-Gallenkamp L, Jansen L, Bertram H, Eberle A, Holleczek B, Schmid-Höpfner S, Waldmann A, Zeissig SR, Brenner H.. Quality of life in long-term and very long-term cancer survivors versus population controls in Germany. Acta Oncol. 2017; 56(2):190-7.

17. Mardani Hamooleh M, Seyedfatemi N, Eslami A, Haghani S. The Spiritual Care Competency of the Nurses of the Teaching Hospitals Affiliated to Alborz University of Medical Sciences, Iran. Iran J. Nurs. 2020; 33 (124):58-69.

18. Jim HS, Pustejovsky JE, Park CL, Danhauer SC, Sherman AC, Fitchett G, Merluzzi TV, Munoz AR, George L, Snyder MA, Salsman JM. Religion, spirituality, and physical health in cancer patients: A meta $\square$ analysis. Cancer. 2015; 121(21):3760-8.

19. Yailagh MS, Ghahfarokhi FK, Maktabi GH, Neasi A, Samavi A. Reliability and validity of the Hope Scale in the Iranian students. J. Life Sci. Biomed. 2012; 2(4):125-8.

20. Biglari Abhari M, Fisher JW, Kheiltash A, Nojomi M. Validation of the persian version of spiritual well-being questionnaires. Iran. J. Med. Sci. 2018; 43(3):276-85.

21. Ahmadi Z, Darabzadeh F, Nasiri M, Askari M. The effects of spirituality and religiosity on well-being of people with cancer: A literature review on current evidences. Jundishapur. J. Chronic Dis. Care. 2015; 4(2):e28386.

22. Rocha ACALd, Ciosak SI. Chronic disease in the elderly: spirituality and coping. Rev. Esc. Enferm. USP. 2014; 48(SPE2):87-93.

23. Counted V, Possamai A, Meade T. Relational spirituality and quality of life 2007 to 2017: an integrative research review. Health Qual. Life Outcomes. 2018; 16(1):1-18

24. Battey BW. Perspectives of spiritual care for nurse managers. J. Nurs. Manag. $2012 ; 20(8): 1012-20$.

25. Ripamonti $\mathrm{Cl}$, Giuntoli F, Gonella S, Miccinesi G. Spiritual care in cancer patients: a need or an option? Curr. Opin. Oncol. 2018; 30(4):212-218.

26. Zumstein-Shaha M, Ferrell B, Economou D. Nurses' response to spiritual needs of cancer patients. Eur J Oncol Nurs. 2020; 48:101792.

27. Costa DT, Silva DMR, Cavalcanti IDL, Gomes ET, Vasconcelos JLA, Carvalho MVG. Religious/spiritual coping and level of hope in patients with cancer in chemotherapy. Rev. Bras. Enferm. 2019; 72(3):640-5.

28. Mansurifard F, Ghaljaei F, Navidian A. The effect of spiritual care on the spiritual health of adolescents with cancer: a pre-experimental study. Med. Surg. Nurs J. 2020; 8(4):e100567.

29. Kang K, Im J, Kim H, Kim S, Song M, Sim S. The effect of logotherapy on the suffering, finding meaning, and spiritual well-being of adolescents with terminal cancer. J. Korean Acad. Child Health Nurs. 2009; 15(2):136-44.

30. Delavari H, Nasirian M. Logo therapy effect on anxiety and depression in mothers of children with cancer. Iran. J. Ped. Hematol. Oncol. 2014; 4(2):42.

31. Caldeira S, Carvalho EC, Vieira M. Spiritual distress- proposing a new definition and defining characteristics. Int. J. Nurs. Knowl. 2013; 24:77-84.

32. Niedzwiedz C L, Knifton L, Robb K A, et al. Depression and anxiety among people living with and beyond cancer: a growing clinical and research priority. BMC Cancer. 2019; 19(1):1-8.

33. Highfield ME. Providing spiritual care to patients with cancer. Clin. J. Oncol. Nurs. 2000; 4(3):115-20.

34. Martins H, Caldeira S. Spiritual distress in cancer patients: a synthesis of qualitative studies. Religions. 2018; 9(10):285

35. Martins H, Dias Domingues T, Caldeira S. Spiritual well-being in cancer patients undergoing chemotherapy in an outpatient setting: a cross-sectional study. J. Holist. Nurs. 2020; 38(1):68-77.

36. Legg, M. J. What is psychosocial care and how can nurses better provide it to adult oncology patients. The Australian J. Adva. Nurs. 2011; 28(3):61-7.

37. MazanecnS, Daly B, Douglas S, Lipson A. The relationship between optimism and quality of life in newly diagnosed cancer patients. Cancer Nurs. 2010; 33(3):235-43.

38. Bernard M, Strasser F, Gamondi C, Braunschweig G, Forster M, Kaspers-Elekes K, Walther Veri S, Borasio GD. Relationship between spirituality, meaning in life, psychological distress, wish for hastened death, and their influence on quality of life in palliative care patients. J. Pain Symptom Manage. 2017; 54(4):514-22. 
39. Salsman J M, Fitchett G, Merluzzi TV, Sherman AC, Park CL. Religion, spirituality, and health outcomes in cancer: A case for a meta-analytic investigation. Cancer. 2015; 121:3754-9.

40. Almuhtaseb MIA, Alby F, Zucchermaglio C, Fatigante M. Religiosity as a cultural resource for arab-palestinian women's coping with cancer. SAGE Open. 2020; 10(1):1-7.

41. Tsai T, Chung U, Chang C, Wang $\mathrm{H}$. Influence of Religious Beliefs on the Health of Cancer Patients. Asian Pac J Cancer Prev. 2016; 17(4): 2315-20.

42. Sadati AK, Lankarani KB, Gharibi V, Fard ME, Ebrahimzadeh N. Religion as an Empowerment Context in the Narrative of Women with Breast Cancer. J. Relig. Health. 2015; 54:1068-79. 